\title{
School climate and the experience of LGBT students: A comparison of the United States and Israel
}

\section{Oren Pizmony-Levy \& Joseph G. Kosciw}

To cite this article: Oren Pizmony-Levy \& Joseph G. Kosciw (2016) School climate and the experience of LGBT students: A comparison of the United States and Israel, Journal of LGBT Youth, 13:1-2, 46-66, DOI: 10.1080/19361653.2015.1108258

To link to this article: http://dx.doi.org/10.1080/19361653.2015.1108258

曲 Published online: 04 May 2016.

Submit your article to this journal 지

Џll Article views: 329

Q View related articles $\longleftarrow$

View Crossmark data ¿ 


\title{
School climate and the experience of LGBT students: A comparison of the United States and Israel
}

\author{
Oren Pizmony-Levy ${ }^{a}$ and Joseph G. Kosciw ${ }^{b}$ \\ aDepartment of International and Transcultural Studies, Teachers College, Columbia University, New York, \\ NY, USA; ${ }^{\mathrm{b}}$ GLSEN (Gay, Lesbian, and Straight Education Network), New York, NY, USA
}

\begin{abstract}
This article examines the school experience of lesbian, gay, bisexual, and transgender (LGBT) students in the United States and Israel. Through comparison of the sociocultural and educational contexts, the authors assess whether school experience of LGBT students differs or operates similarly across countries. The authors use data from the National School Climate Survey conducted in 2007 in the United States and the Israeli School Climate Survey conducted in 2008 in Israel. In comparison with their Israeli counterparts, LGBT students in the United States were more likely to experience assault and harassment in schools but were more likely to have access to LGBT supportive resources in their schools. Results from multi-variate analysis show that negative school climate affect absent-eeism and school belonging similarly for both countries.
\end{abstract}

\section{ARTICLE HISTORY}

Received 27 September 2015

Accepted 12 October 2015

\section{KEYWORDS}

School climate; LGBT youth; NGOs; Israel; United States; comparative education

\section{Introduction}

The past decade saw an immense growth in the production of knowledge about the school experience of lesbian, gay, bisexual, and transgender (LGBT) students. A recent review conducted by the United Nations Educational, Scientific, and Cultural Organization (UNESCO) encompassed reports from more than 20 countries across the globe (UNESCO, 2012). These single-country studies suggest that homophobic and transphobic bullying and discrimination in schools sadly may be universal (for example, see Hillier et al. [2010] for Australia; Pizmony-Levy et al. [2008] for Israel; Takacs [2006] for the European Union; and Taylor et al. [2011] for Canada). Regardless of the social status of homosexuality and LGBT people, the school experience of LGBT students is challenging. Drawing on this body of evidence, UNESCO defined homophobic and transphobic bullying as a global problem that is a violation of students' rights and that it impedes educational success for LGBT students (Cornu, 2016; UNESCO, 2012).

CONTACT Oren Pizmony-Levy op2183@tc.columbia.edu $=$ Department of International and Transcultural Studies, Teachers College, Columbia University, 525 West 120th Street, New York, NY 10027. 
Much of existing research on LGBT student experiences, however, has come from the United States (see Kosciw, Greytak, Palmer \& Boesen, 2014) and has mostly focused on the experiences of anti-LGBT victimization and its consequences, such as higher rates of suicidal thoughts and attempts, substance use, and sexual risk behaviors (Bontempo \& d'Augelli, 2002; Toomey, Ryan, Diaz, Card, \& Russell, 2010). In the context of growing attention to safer school environments, studies in the United States have recently demonstrated the elevated rates of victimization and bullying that LGBT youth experience at school, and more recently have focused on the contexts and characteristics of schools that may support negative attitudes and behaviors toward LGBT youth (Horn, Kosciw, \& Russell, 2009).

Although research on the experience of LGBT students has been conducted in multiple social contexts, we have little comparative research in this field (Kosciw \& Pizmony-Levy, 2013). We credit this gap to the fact that more often than not scholars have used different research design and/or instruments. Having comparative research on the experience of LGBT students could contribute to the further development of scholarship and practice. In his introduction to the report on the first-ever international study of student achievement, Foshay (1962) wrote, "If custom and law define what is educationally allowable within a nation, the educational systems beyond one's national boundaries suggest what is educationally possible. The field of comparative education exists to examine these possibilities" (p. 7). Comparative research on school experience of LGBT students could shed light on how this population is served in different social contexts and educational systems, and, in turn, point to best practices and possibilities. In addition, comparative research on the experiences of LGBT students would allow us to test whether theoretical frameworks developed in one context-most often, the United Statescould be generalized to other contexts (Arnove, Torres, \& Franz, 2012). Furthermore, comparative research would allow us to test how contextual factors-for example, the cultural acceptance of LGBT people and educational policy-shape the experience of LGBT students at school (Bray, Adamson, \& Mason, 2007). These important developments are possible once we compare two or more social contexts.

The present study uses national data on LGBT secondary school students collected by national nongovernmental organizations (NGOs) in each country-the GLSEN (Gay, Lesbian, and Straight Education Network) in the United States and Israeli Gay Youth (IGY) in Israel. Specifically, we examined the following:

1. The differences between the two LGBT student populations on (a) indicators of hostile school climate for LGBT students (i.e., anti-LGBT remarks and experiences of victimization), and (b) the availability of LGBT affirmative school resources (i.e., access to LGBT community information in textbooks and online; number of supportive educators, and access to LGBT supports in extracurricular activities); and

2. The relation between negative school climate and academic indicators (i.e., missing school and school belonging). 


\section{Background}

\section{School climate and LGBT students}

Over the past three decades, scholars have increasingly recognized the importance of K-12 school climate (Thapa, Cohen, Guffey, \& Higgins-D’Alessandro, 2013). School climate is seen as a school improvement strategy that promotes safer, more supportive, and more inclusive learning environment (Thapa et al., 2013). With regard to LGBT youth, recent research has demonstrated the negative impact of peer victimization on psychological adjustment and how that serves as a pathway to poorer academic outcomes (Kosciw, Palmer, Kull, \& Greytak, 2013). Yet, research has also documented how affirmative supports for LGBT students at school can contribute to better school climates for LGBT as well as the well-being and academic success of these students (Kosciw, Greytak, Palmer, \& Boesen, 2014; Kosciw et al., 2013; Toomey \& Russell, 2013; Toomey, Ryan, Diaz, \& Russell, 2013).

\section{Setting the stage: The United States and Israel}

To contribute to our understanding of anti-LGBT discrimination and violence in the school context globally, it is important to begin to explore comparisons across countries on LGBT student experience. In this article, we focus our comparative analysis on the United States and Israel, two nations that share many similarities. They are both Western, democratic, and industrialized societies with advanced K-12 educational systems. On the 2007 Human Development Index, a summary measure of average achievement in key dimensions of human developmenthealth, education, and decent standard of living, both countries had very high scores (United States: 0.956; Israel: 0.935). Yet, on the GINI Index, a commonly used index on economic inequality, both nations have relatively low ratings, indicating higher levels of inequality (United States: 40.8; Israel: 39.2; UNDP, 2009).

With respect to education, both the United States and Israel have large populations of those younger than 15 years of age (20\% and $28 \%$, respectively), which means that educational systems in both countries are faced with high demand and pressure. Public spending on education, measured as percent of GDP, is similar across countries (United States: 5.5\% and Israel: 5.9\%) and relatively higher than the average of Organization for Economic Co-operation and Development countries. With regard to academic achievement, results from the 2007 Trends in International Mathematics and Science Study (Martin, Mullis, \& Foy, 2008; Mullis, Martin, \& Foy, 2008) show that students in the United States perform better than do students in Israel in mathematics (U.S. students: 508 vs. Israeli students: 463) and science (U.S. students: 520 vs. Israeli students: 468).

The importance of school climate for the experience of LGBT students makes it crucial to put the comparison into a broader context of school safety. That is, the experience of LGBT students could be a reflection of the broader context of school 
safety. Findings from the 2001/2002 Health Behavior in School-Aged Children Study (Currie et al., 2004) shed light on the experience of 15-years-old students with bullying. The overall prevalence of bullying in schools, as measured by percent of 15-year-olds reporting that they were bullied at least once in the previous couple of months, is similar for boys (United States: $31.3 \%$; Israel: $31.5 \%$ ), but different for girls (United States: 26.2\%; Israel: 16.3\%). These data are more than a decade old, and the phenomenon of bullying and the nature of school climate in general may likely have changed in that time. In recent years in the United States, bullying has gained significant national media coverage. In 2001, very few states had antibullying laws; as of 2015, a majority of U.S. states do, including 18 that include protections for sexual orientation, gender identity, and gender expression. It is possible that both the phenomenon of bullying alone may have increased in the United States, and greater national attention may have increased awareness and reporting. Neither government has national indicators on education and school climate that allow for the examination of LGBT students as compared with their heterosexual cisgender peers.

One important difference between the United States and Israel is the location of educational policy center-who makes decisions? The education system in the United States is highly decentralized; thus, policies and practices can vary considerably from state to state and across school districts (Organisation for Economic Cooperation and Development [OECD], 2012). In Israel, in contrast, the education system is relatively more centralized, financed by the national government and directed by the Ministry of Education. Over the past two decades, however, local authorities and schools have gained autonomy over different aspects of the budget and curriculum (OECD, 2012; Volansky, 2007). Because the two counties vary in the location of educational policy center, there are a number of ways that demand for reform in the system (i.e., making schools more welcoming to LGBT students and families) may be handled differently in these countries. For example, we might expect to find more reactivity-such as supportive resources-in the United States than in Israel.

In addition to characteristics of the education system, the experience of LGBT students in schools might be affected by the social status of homosexuality and LGBT individuals. According to the Pew Global Attitudes Survey, Israelis are less accepting of homosexuality than are Americans (Pew Charitable Trusts, 2007). Nearly half of Americans (49.0\%) say that homosexuality should be accepted by society compared with less than two fifths of Israelis who believe so (38.0\%). Furthermore, among Americans, this percentage is higher with younger adults (ages 18-29 years), whereas it remains similar among the Israeli population: $70 \%$ of younger Americans and versus $40 \%$ of younger Israelis express tolerant views toward homosexuality. This may be, in part, because the social movement for the rights of LGBT individuals emerged in the United States more than two decades before it emerged in Israel (Adam, Duyvendak, \& Krouwel, 2009; Kama, 2000). Thus, younger adults in the United States may be more aware of the LGBT 
community and movement during their early life in comparison with younger adults in Israel.

Although the societal attitudes towards LGBT people in Israel are lower than in the United States, legal protections for LGBT people in Israel have advanced more quickly. For example, the decriminalization of homosexuality took place in Israel in 1988 (Harel, 1999), whereas in the United States it took place in 2003 (Lawrence $v$. Texas). Israeli laws also protect from discrimination in the workplace on the basis of sexual orientation, but not gender identity (Harel, 1999), whereas in the United States there are no federal laws and protection varies by state. Last, the formal ban from military service of openly LGBT soldiers was removed in Israel in 1993 and in the United States in 2010. The expansion of LGBT rights in Israel was made mostly through the court system (especially the Supreme Court and the High Court of Justice) and-to lesser extent-through the political system and public discourse. In contrast, in the United States, given its federal system, progressive laws regarding LGBT people have been enacted at the state level, particularly with nondiscrimination and marriage, but not at the national level.

\section{Method}

\section{Data sources}

We used data from national surveys on LGBT students and their experiences in school from the United States and Israel to examine differences in the student experiences with regard to school climate and in the relation between school climate and engagement of LGBT students. Data for the United States come from the 2007 National School Climate Survey (Kosciw, Diaz, \& Greytak, 2008). The survey has been conducted biennially since 1999 by GLSEN, a national education organization focused on ensuring safe schools for all students. The GLSEN survey uses multiple methods to obtain a more representative sample of LGBT youth: outreach through community-based groups serving LGBT youth and outreach via the Internet. Data for Israel come from the 2008 Israeli School Climate Study (the IGY survey; Shilo \& Pizmony-Levy, 2008). The survey has been conducted every 4 years since 2004 by the IGY, a professional organization dedicated to empowering LGBT youth within the formal and informal education systems. The IGY survey is based on previous work of GLSEN; most of the items of the original questionnaire were translated into Hebrew and adapted to better reflect the Israeli context. It also uses multiple strategies to obtain a more representative sample of LGBT youth. Although the methods for locating respondents are similar across both surveys, in 2007/2008, the diffusion of Internet usage in the United States was higher than in Israel (74.0 vs. 59.4 Internet users per 100 people; World Bank Group, 2016). Thus, the low diffusion of Internet usage in Israel increases the risk of selection bias as access to the Internet is strongly associated with social location.

The GLSEN and IGY surveys were conducted to inform evidence-based solutions to K-12 schools and to support advocacy efforts in each country, and the 
surveys were not conducted for the purpose of comparative research. Therefore, as we subsequently discuss, they are not fully compatible. Nevertheless, because the IGY survey is based on the GLSEN survey, we argue that these surveys are sufficiently equivalent and provide the best data available to address the objectives of this study.

\section{Measures}

Table 1 provides item wording and metrics for all the variables used in the analysis. There are slight differences in how some of these variables were measured in the United States and in Israel, and there are cases when a specific variable was not available in one country. To facilitate comparison between countries, variables were recoded into a similar scale.

\section{Dependent variables}

This study examines two dependent variables: absenteeism and school belonging.

\section{Absenteeism}

Respondents were asked to indicate how many days they did not go to school because they felt uncomfortable or unsafe at school or on the way to or from school. In the GLSEN and IGY questionnaires, absenteeism was measured on a 5 point scale ranging from 1 (zero times/days) to 5 (six or more times/days). Because these items had heavily skewed distribution (with majority of respondents not skipping a day of school), we recoded the variable as binary: 0 (no) and 1 (yes).

\section{School belonging}

In both surveys, this construct was assessed with the Psychological Sense of School Membership scale developed for use with adolescents (Goodenow, 1993). The measure, reported on a 4-point Likert-type scale, includes 18 items such as "Other students in my school take my opinions seriously" and "I feel like a real part of my school." The mean of the 18 items was used in the analyses for both samples, with higher scores meaning higher levels of belonging to school. The reliability of this scale was high (Cronbach's $\alpha=.91$ for the GLSEN survey and .93 for the IGY survey).

\section{Independent variables}

\section{Homophobic remarks}

The first set of variables assesses exposure to homophobic remarks at school. In the GLSEN survey, respondents were asked to indicate the frequency of hearing the word gay used in a negative way (such as "That's so gay" or "You're so gay") and other homophobic remarks (such as "faggot," "dyke," or "queer" used in a negative manner). In the IGY survey, respondents were asked three items to indicate the 
Table 1. Survey item wording, by country.

\begin{tabular}{|c|c|c|}
\hline Variable & Wording in the GLSEN Survey & Wording in the IGY Survey \\
\hline \multicolumn{3}{|c|}{ Exposure to homophobic remarks } \\
\hline \multirow[t]{2}{*}{$\begin{array}{l}\text { Hearing "gay" used in } \\
\text { a negative way }\end{array}$} & $\begin{array}{l}\text { How often do you hear the word "gay" } \\
\text { used in a negative way (such as } \\
\text { "That's so gay" or "You're so gay") } \\
\text { in school? Original scale: never, } \\
\text { rarely, sometimes, often, and } \\
\text { frequently }\end{array}$ & \\
\hline & & $\begin{array}{l}\text { How often do you hear the word } \\
\text { "homo" used in a negative way in } \\
\text { school? Original scale: never, } \\
\text { rarely, sometimes, often, and } \\
\text { frequently }\end{array}$ \\
\hline $\begin{array}{l}\text { Hearing "lesbian" used } \\
\text { in a negative way }\end{array}$ & & $\begin{array}{l}\text { How often do you hear the word } \\
\text { "lesbian" used in a negative way } \\
\text { in school? Original scale: never, } \\
\text { rarely, sometimes, often, and } \\
\text { frequently }\end{array}$ \\
\hline $\begin{array}{l}\text { Hearing other } \\
\text { homophobic remarks }\end{array}$ & $\begin{array}{l}\text { How often have you heard other } \\
\text { homophobic remarks used in } \\
\text { school (such as "faggot," "dyke," or } \\
\text { "queer" used in a negative } \\
\text { manner)? Original scale: never, } \\
\text { rarely, sometimes, often, and } \\
\text { frequently }\end{array}$ & $\begin{array}{l}\text { How often have you heard other } \\
\text { homophobic remarks used in } \\
\text { school (such as "faggot," or } \\
\text { "queer" used in a negative } \\
\text { manner)? Original scale: never, } \\
\text { rarely, sometimes, often, and } \\
\text { frequently }\end{array}$ \\
\hline \multicolumn{3}{|c|}{ Experience with harassment and assault } \\
\hline Verbal harassment & $\begin{array}{l}\text { In the past year, how often have you } \\
\text { been verbally harassed (name } \\
\text { calling, threats, etc. directed at you) } \\
\text { at your school because of your } \\
\text { sexual orientation? Original scale: } \\
\text { never, rarely, sometimes, often, and } \\
\text { frequently }\end{array}$ & $\begin{array}{l}\text { In the past year, how often have you } \\
\text { been verbally harassed (name } \\
\text { calling, threats, etc.) at your } \\
\text { school because of your sexual } \\
\text { orientation? Original scale: never, } \\
\text { rarely, sometimes, often, and } \\
\text { frequently }\end{array}$ \\
\hline Physical assault & $\begin{array}{l}\text { In the past year, how often have you } \\
\text { been physically assaulted (punched, } \\
\text { kicked, injured with a weapon) at } \\
\text { your school because of your sexual } \\
\text { orientation? Original scale: never, } \\
\text { rarely, sometimes, often, and } \\
\text { frequently }\end{array}$ & $\begin{array}{l}\text { In the past year, how often have you } \\
\text { been physically assaulted } \\
\text { (punched, kicked, cold weapon) at } \\
\text { your school because of your } \\
\text { sexual orientation? Original scale: } \\
\text { never, rarely, sometimes, often, } \\
\text { and frequently }\end{array}$ \\
\hline Sexual harassment & $\begin{array}{l}\text { How often have you been sexually } \\
\text { harassed at your school, such as } \\
\text { sexual remarks made toward you or } \\
\text { someone touching your body } \\
\text { inappropriately? Original scale: } \\
\text { never, rarely, sometimes, often, and } \\
\text { frequently }\end{array}$ & $\begin{array}{l}\text { How often have you been sexually } \\
\text { harassed at your school (sexual } \\
\text { remarks made toward you or } \\
\text { someone touching your body } \\
\text { inappropriately)? Original scale: } \\
\text { never, rarely, sometimes, often, } \\
\text { and frequently }\end{array}$ \\
\hline
\end{tabular}

Supportive resources for LGBT students

Books and other resources in school library

Access to websites in school
How many books or other resources in your school library contain information about LGBT people, history or events? Scale: none, a few, many, don't know

Are you able to use school computers to access websites about LGBT people, history or events? Scale: yes, no, don't know, don't have Internet access at my school
Does your school library have books or other resources that contain information about LGBT people? Scale: yes, no, don't know

Are you able to use school computers to access websites about LGBT? Scale: yes, no, don't know 
Table 1. (Continued)

\begin{tabular}{|c|c|c|}
\hline Variable & Wording in the GLSEN Survey & Wording in the IGY Survey \\
\hline \multirow[t]{2}{*}{ Extracurricular activities } & $\begin{array}{l}\text { Does your school have a gay-straight } \\
\text { alliance (GSA) or another type of } \\
\text { club that addresses LGBT student } \\
\text { issues? Scale: yes, no }\end{array}$ & \\
\hline & & $\begin{array}{l}\text { Does your school cooperate with } \\
\text { organizations or groups that assist } \\
\text { students who are LGBT? Scale: } \\
\text { yes, no, don't know }\end{array}$ \\
\hline Supportive teachers & $\begin{array}{l}\text { How many teachers or other school } \\
\text { staff persons are supportive of } \\
\text { LGBT students at your school? } \\
\text { Scale: none, one, between } \\
2 \text { and } 5, \text { between } 6 \text { and } 10, \\
\text { more than } 10\end{array}$ & $\begin{array}{l}\text { Does your school have teachers or } \\
\text { other school staff persons who } \\
\text { signal they are supportive of } \\
\text { students who are LGBT? Scale: } \\
\text { yes, no, don't know }\end{array}$ \\
\hline \multicolumn{3}{|l|}{ Outcomes } \\
\hline Absenteeism & $\begin{array}{l}\text { In the past month of school, how } \\
\text { many days did you not go } \\
\text { to school because you felt } \\
\text { uncomfortable or unsafe at } \\
\text { school or on your way to or } \\
\text { from school? Scale: } 0 \text { days, } 1 \text { day, } \\
2 \text { or } 3 \text { days, } 4 \text { or } 5 \text { days, } 6 \text { or } \\
\text { more days }\end{array}$ & $\begin{array}{l}\text { In the past month of school, how } \\
\text { many days did you not go to } \\
\text { school because you felt } \\
\text { uncomfortable or unsafe at school } \\
\text { or on your way to or from school? } \\
\text { Scale: } 0 \text { days, } 1 \text { day, } 2 \text { or } 3 \text { days, } 4 \\
\text { or } 5 \text { days, } 6 \text { or more days }\end{array}$ \\
\hline Sense of belonging to school & $\begin{array}{l}\text { Psychological Sense of School } \\
\text { Membership Scale (Goodenow, } \\
\text { 1993), which includes } 18 \text { 4-point } \\
\text { Likert-type items. }\end{array}$ & $\begin{array}{l}\text { Psychological Sense of School } \\
\text { Membership Scale (Goodenow, } \\
\text { 1993), which includes } 18 \text { 4-point } \\
\text { Likert-type items. Items were } \\
\text { translated to Hebrew by research } \\
\text { team. }\end{array}$ \\
\hline
\end{tabular}

Note. GLSEN = Gay, Lesbian, and Straight Education Network; IGY = Israeli Gay Youth; LGBT = lesbian, gay, bisexual, and transgender.

frequency of hearing various pejorative remarks (hearing "homo" or "lesbian" in a negative way and other types of homophobic remarks, such as "faggot"). In the GLSEN and the IGY questionnaires, these variables were measured with 5-point Likert-type scale ranging from 1 (never) to 5 (frequently). In each sample, the correlations between items were positive, medium-sized, and significant $(p<.01)$. In the GLSEN survey, the items hearing the word "gay" and hearing other remarks are moderately correlated $(r=.42)$. In the IGY survey, the items hearing the word "homo" and hearing the word "lesbian" are weakly correlated $(r=.29)$, the items hearing the word "homo" and other remarks are moderately correlated $(r=.64)$, and the items hearing the word "lesbian" and other remarks are moderately correlated $(r=.35)$. The mean was computed of the homophobic remarks items in each sample.

\section{Victimization}

Respondents were asked to indicate the frequency of verbal harassment (e.g., name-calling, threats), physical assault (e.g., punching, kicking), and sexual harassment (e.g., sexual remarks, inappropriately touching). In the GLSEN and the IGY questionnaires, these variables were measured on a 5-point Likert-type scale ranging from 1 (never) to 5 (frequently). 


\section{Supportive resources for LGBT students}

We examined four types of school resources:

Textbooks and other resources. Respondents were asked whether their textbooks or other materials in the school library contained information about LGBT people, history or events: 0 (no) and 1 (yes).

Internet access to LGBT information. Respondents were asked whether they had access to LGBT information and community websites from school computers: $0=$ no; $1=$ yes.

LGBT-related extracurricular activities. In the United States, respondents were asked to indicate whether their schools have a gay-straight alliance or another type of club that addresses LGBT student issues. In Israel, where school clubs are not common in general, however, respondents were asked to indicate whether their schools host guest lectures/workshops by LGBT NGOs (for a detailed description of this intervention, see Eick, Rubinstein, Hertz, \& Slater, 2016). Although these items assess slightly different activities, we maintain that they are somewhat comparable indicators of school support for LGBT students as they capture activities or learning experiences that complement the academic curriculum. Both items were recoded as binary: 0 (no) and 1 (yes).

Supportive teachers. In the United States, respondents were asked how many teachers or other school staff persons are supportive of LGBT students. In Israel, however, respondents were asked whether their school has teachers or other school staff persons who signal they are supportive of LGBT students. For comparability, we recoded these variables as binary: 0 (no) and 1 (yes).

\section{Control variables}

\section{Personal demographics}

Participants in both surveys self-reported their gender, age, race, and ethnicity. Gender was coded into three groups: male, female, and transgender. Sexual orientation was coded into three groups: gay/lesbian, bisexual, other. In the GLSEN survey, race and ethnicity were coded into six groups: white, Black/African American, Asian American, Native American, Latino/a, and other. In the IGY survey, ethnicity was coded into three groups: European Jew, Mizrahi Jew, and Arab.

\section{Degree of outness}

Participants were asked the extent to which respondents are out to people in school and to their family in both surveys, but somewhat differently. In the GLSEN survey, respondents were asked two questions about the extent to which they are out to people at school: (a) to students and (b) teachers and other school staff: 0 (none), 1 (out to some), 2 (out to most) and 3 (out to all). In addition, participants in the GLSEN survey were asked whether they were out to one or more parent/ guardian. In the IGY survey, however, respondents were provided a list of people/ groups and asked to whom they were out and to check all that applied: father, 
mother, siblings, close friend, one teacher, most teachers, school staff, and all students. Respondents were also asked whether they are not out to anyone. To have comparable indicators of outness, we recoded the outness variable in each sample to indicate not being out at all: 0 (out to anyone) and 1 (out to no one).

\section{Samples}

After listwise deletion of missing information, the sample from the United States consisted of a total of 5,242 respondents and the sample from Israel consisted of a total of 408 respondents. Table 2 presents descriptive statistics for demographic characteristics of these samples. Compared with the sample from the United States, the sample from Israel included more cisgender males than cisgender females, and more respondents who identify as gay or lesbian than respondents who identify as bisexuals. On average, respondents in the sample from the United States were younger than respondents in the sample from Israel. With respect to outness, a small minority of LGBT youth in the United States were not out (3.5\%) whereas in Israel slightly more than one tenth $(10.8 \%)$ were not out.

\section{Analytical strategy}

To address the research questions that guide this study, we began with descriptive statistics of school climate and academic engagement in the United States and Israel. We conducted a series of chi-square tests and $t$ tests for independent means

Table 2. Sample demographics, by country.

\begin{tabular}{|c|c|c|c|c|c|}
\hline & \multicolumn{2}{|c|}{ United States $(n=5,242)$} & \multicolumn{2}{|c|}{ Israel $(n=408)$} & \multirow[b]{2}{*}{ Test } \\
\hline & $M$ or $\%$ & $S D$ & $M$ or $\%$ & $S D$ & \\
\hline \multicolumn{6}{|l|}{ Gender } \\
\hline Men & 33.20 & & 54.50 & & $\chi^{2}=76.45^{* * *}$ \\
\hline Women & 58.50 & & 43.50 & & $\chi^{2}=34.86^{* * *}$ \\
\hline Transgender & 4.50 & & 2.00 & & $\chi^{2}=6.08^{* * *}$ \\
\hline Other gender & 3.80 & & - & & \\
\hline Age & 15.90 & 1.31 & 16.54 & 1.34 & $t=9.48^{* * *}$ \\
\hline \multicolumn{6}{|l|}{ Sexual orientation } \\
\hline Gay/lesbian & 53.50 & & 66.00 & & $\chi^{2}=23.77^{* * *}$ \\
\hline Bisexual & 42.10 & & 29.60 & & $\chi^{2}=24.33^{* * *}$ \\
\hline Other & 4.40 & & 4.40 & & $\chi^{2}=0.00$ \\
\hline \multicolumn{6}{|l|}{ Race/ethnicity } \\
\hline Ashkenazi & - & & 79.20 & & \\
\hline Mizrahi & - & & 13.70 & & \\
\hline Arab & - & & 7.10 & & \\
\hline White non-Hispanic & 81.80 & & - & & \\
\hline Asian/Pacific Islander & 4.90 & & - & & \\
\hline Hispanic & 16.20 & & - & & \\
\hline African American/Black & 8.50 & & - & & \\
\hline Native American & 10.00 & & - & & \\
\hline Other & 1.60 & & - & & \\
\hline Not out to people & 3.55 & & 10.76 & & $\chi^{2}=50.51^{* * *}$ \\
\hline
\end{tabular}

${ }^{* * *} p<.001$. 
to compare the two samples. Then, we conducted two separate multivariate analyses to examine the relationships between school climate indicators and academic outcomes. For absenteeism, because it was a dichotomous outcome variable, we estimated logistic regression models (Long, 1997). For school belonging, we estimated an ordinary least square regression. In each analysis, covariates were entered on the first step, followed by exposure to homophobic remarks on the second step, and the set of victimization variables on the final step.

\section{Results}

\section{Descriptive statistics}

\section{School climate}

Table 3 presents descriptive statistics of school climate in the United States and Israel. For LGBT student in both countries, hearing homophobic remarks at school was a common occurrence. Nearly three quarters (72.2\%) of respondents in the United States said they frequently heard the word gay used in a negative way (such as "That's so gay" or "You're so gay") and slightly more than two fifths $(44.8 \%)$ heard other types of homophobic remarks. In Israel, over half $(55.6 \%)$ of respondents said that they frequently hear the word "homo" used as pejorative remark; one third (33.2\%) heard other types of homophobic remarks, and small fraction (7.6\%) heard the word "lesbian" used as pejorative remark. On the combined remarks variable, the mean for the United States sample was significantly higher than that for the Israel sample (see also Table 3).

With regard to experiences of harassment and assault, overall, verbal harassment was the most common and frequent form of harassment in school: almost half of the U.S. LGBT students (46.4\%) reported they have been harassed often or frequently, whereas in Israel less than a quarter $(13.7 \%)$ reported they have been harassed often or frequently. In the United States, slightly more than one fourth of the students (26.4\%) reported they have been sexually harassed and close to one tenth of the students (8.1\%) reported they have been physically assaulted. In contrast, in Israel, these figures are nominal (3\%). On all three victimization variables, the mean was higher for respondents in the United States than those in Israel.

\section{Supportive resources}

Table 3 also shows descriptive statistics on LGBT supportive school resources. With the exception of supportive teachers, less than half of the respondents reported having access to important resources in their school. For example, $42 \%$ of U.S. LGBT youth and 15\% of Israeli LGBT youth reported having access to LGBT information in books and other resources in the library. Slightly more than four fifths of U.S. respondents (83\%) and half of Israeli respondents identified having at 
Table 3. School climate, by country.

\begin{tabular}{|c|c|c|c|c|c|}
\hline & \multicolumn{2}{|c|}{ United States $(n=5,242)$} & \multicolumn{2}{|c|}{ Israel $(n=408)$} & \multirow[b]{2}{*}{ Test } \\
\hline & $M$ or $\%$ & $S D$ & $M$ or $\%$ & $S D$ & \\
\hline Homophobic remarks (scale) & 4.38 & 0.69 & 3.39 & 0.89 & $t=27.61^{* * *}$ \\
\hline Verbal harassment $(1-5)$ & 3.32 & 1.37 & 2.00 & 1.09 & $t=18.99^{* * *}$ \\
\hline Physical assault (1-5) & 1.50 & 1.09 & 1.30 & 0.70 & $t=3.76^{* * *}$ \\
\hline Sexual harassment (1-5) & 2.61 & 1.35 & 1.41 & 0.75 & $t=17.65^{* * *}$ \\
\hline Books and resources (\% yes) & 41.53 & & 15.16 & & $\chi^{2}=110.29^{* * *}$ \\
\hline Websites (\% yes) & 29.95 & & 45.48 & & $\chi^{2}=42.70^{* * *}$ \\
\hline Extra curriculum (\% yes) & 36.20 & & 11.25 & & $\chi^{2}=104.61^{* * *}$ \\
\hline Supportive teachers (\% yes) & 82.87 & & 51.10 & & $\chi^{2}=244.59^{* * *}$ \\
\hline Absenteeism (\% yes) & 33.31 & & 16.38 & & $\chi^{2}=49.88^{* * *}$ \\
\hline Sense of belonging to school (scale) & 2.54 & 0.61 & 2.74 & 0.65 & $t=6.55^{* * *}$ \\
\hline
\end{tabular}

${ }^{* * *} p<.001$.

least one educator who was supportive of LGBT students at school. For all resources examined in this study, except for Internet access to LGBT information, U.S. LGBT youth were more likely to report having them in their schools than did the Israeli LGBT youth.

\section{Academic engagement}

Table 3 shows descriptive statistics on LGBT students' engagement in school. In the U.S. sample, one third (33.3\%) of LGBT students reported skipping a day of school, whereas in Israel one sixth (16.5\%) of the LGBT students reported skipping a day of school. When comparing the means on school belonging, LGBT students in the United States had lower degree of belonging to their school community than their counterparts in Israel.

\section{Multivariate analysis}

Table 4 presents findings from the logistic regression analysis for absenteeism. The first two models present coefficients based on the sample from the United States, and last two models present coefficients based on the sample from Israel. The first model for each country includes exposure to homophobic remarks in school. The second model for each country introduces experience of harassment and assault in school. All models include demographic controls (gender, age, sexual orientation, and relevant categories of race and ethnicity; available from the authors upon request).

Overall, negative school climate was associated with absenteeism among LGBT students. In both countries, frequent exposure to homophobic remarks increased the likelihood of absenteeism (Model 1). The effect, however, was statistically different across countries. In the United States, a change of one standard deviation in exposure to homophobic remarks increased the odds of absenteeism by a factor of 1.5 , whereas in Israel, this change increased the odds of absenteeism by a factor of 
Table 4. Unstandardized coefficients for logistic regression of missing one day of school (absenteeism), by country.

\begin{tabular}{|c|c|c|c|c|}
\hline & \multicolumn{2}{|c|}{ United States $(n=5,242)$} & \multicolumn{2}{|c|}{ Israel $(n=408)$} \\
\hline & Model 1 & Model 2 & Model 1 & Model 2 \\
\hline Homophobic remarks & $\begin{array}{l}.561^{* * *} \\
(.049)\end{array}$ & $\frac{.111^{*}}{(.055)}$ & $\begin{array}{l}.947^{* * *} \\
(.188)\end{array}$ & $\frac{.616^{* *}}{(.204)}$ \\
\hline Verbal harassment & & $\begin{array}{l}.341^{* * *} \\
(.031)\end{array}$ & & $\begin{array}{c}.241 \\
(.160)\end{array}$ \\
\hline Physical assault & & $\begin{array}{l}.453^{* * *} \\
(.035)\end{array}$ & & $\begin{array}{l}.626^{* *} \\
(.213)\end{array}$ \\
\hline Sexual harassment & & $\begin{array}{l}.202^{* * *} \\
(.026)\end{array}$ & & $\begin{array}{l}.374^{*} \\
(.176)\end{array}$ \\
\hline Intercept & -.719 & $-3.015^{* * *}$ & $-4.181^{*}$ & $-5.911^{* *}$ \\
\hline Pseudo $R^{2}$ & .045 & .158 & .096 & .194 \\
\hline
\end{tabular}

Note. Standard errors in parentheses. All models include controls for gender, age, sexual orientation, country-specific categories of race/ethnicity, and outness. Shaded areas indicate that the coefficient for Americans is significantly different from the coefficient for Israelis.

${ }^{*} p<.05 ;^{* *} p<.01{ }^{* * *} p<.001$.

2.3. The effect of exposure to homophobic remarks held even after controlling for other elements of school climate (Model 2).

Experience of assault and harassment also increased absenteeism (Model 2). In both countries, experience with physical assault and sexual harassment had positive and significant relationship with absenteeism. However, a difference emerged in the effect of verbal harassment. While verbal harassment is insignificant in Israel, experience of verbal harassment had a positive and significant relationship with absenteeism in the United States.

Table 5 presents the findings from the ordinary lease square regression analysis for sense of belonging to school. Following the previous analysis, we estimated two models. In both countries, frequent exposure to homophobic remarks decreased school belonging. This pattern held even after introducing other elements of school climate (Model 2). In the United States, all types of experience of assault and harassment (verbal, physical, and sexual) had negative and significant relationship with sense of belonging to school. In Israel, however, only verbal harassment and sexual harassment have negative and significant relationship with sense of belonging to school.

\section{Supplemental analyses}

We conducted several methodological checks on our results (available on request). First, we used ordinal logistic regression (Long, 1997) and ordinary lease square regression to analyze the original variable for absenteeism (which includes five categories). Patterns were consistent across all methods and models, suggesting that our results are not an artifact of the transformation of the original variable into a binary variable. 
Table 5. Unstandardized coefficients for ordinary least square regression of sense of belonging to school, by country.

\begin{tabular}{|c|c|c|c|c|}
\hline & \multicolumn{2}{|c|}{ United States $(n=5,242)$} & \multicolumn{2}{|c|}{ Israel $(n=408)$} \\
\hline & Model 1 & Model 2 & Model 1 & Model 2 \\
\hline Homophobic remarks & $\begin{array}{c}-.264^{* * *} \\
(.011)\end{array}$ & $\begin{array}{c}-.152^{* * *} \\
(.012)\end{array}$ & $\begin{array}{c}-.211^{* * *} \\
(.035)\end{array}$ & $\begin{array}{c}-.129^{* * *} \\
(.036)\end{array}$ \\
\hline Verbal harassment & & $\begin{array}{c}-.103^{* * *} \\
(.007)\end{array}$ & & $\begin{array}{c}-.120^{* * *} \\
(.034)\end{array}$ \\
\hline Physical assault & & $\begin{array}{c}-.086^{* * *} \\
(.008)\end{array}$ & & $\begin{array}{c}-.073 \\
(.053)\end{array}$ \\
\hline Sexual harassment & & $\begin{array}{c}-.031^{* * * *} \\
(.006)\end{array}$ & & $\begin{array}{r}-.102^{*} \\
(.042)\end{array}$ \\
\hline Intercept & $2.672^{* * *}$ & $3.232^{* * *}$ & $2.799^{* * *}$ & $3.064^{* * *}$ \\
\hline Adjusted $R^{2}$ & .154 & .261 & .102 & .182 \\
\hline
\end{tabular}

Note. Standard errors in parentheses. All models include controls for gender, age, sexual orientation, country-specific categories of race/ethnicity, and outness.

${ }^{*} p<.05 ;{ }^{* * *} p<.001$.

Second, we analyzed the models with the original items for exposure to homophobic remarks instead of the scale (see Table 2 for the wording of each item). Overall, patterns were consistent across all models. The only exception is the model for absenteeism in the United States with the variable hearing the word gay used in a negative way. Once controlling for victimization, the effect of exposure to homophobic remarks turned insignificant.

We analyzed the models without controls for race/ethnicity to ensure that these variables - which are measured differently across surveys-did not affect the results. Similarly, we analyzed the models without controls for the variable outness. The removal of these controls did not change the patterns of the key independent variables.

\section{Discussion}

Prior research has demonstrated that school is often not a safe or affirming environment for LGBT youth (UNESCO, 2012), and the present study expands upon this research by offering an understanding of the similarities and differences of these phenomena in two country contexts. Findings indicate that in U.S. and Israeli schools, LGBT youth often hear homophobic remarks at school and experiences of anti-LGBT victimization are common. This study also highlights the importance of considering the contexts that LGBT youth inhabit to better understand their school experiences.

\section{Comparisons in school climate}

Although hearing homophobic remarks was common in both countries, respondents in the United States were more likely to hear homophobic remarks at school than their Israeli peers. Furthermore, U.S. LGBT youth reported higher levels of harassment and assault. Taken together, these findings suggest that schools in the United States may be more hostile to LGBT students than schools in Israel. These differences that we found in the experiences of LGBT youth in the United States 
and Israel may also reflect general differences in school safety. Recent data from 2007 Trends in International Mathematics and Science Study has shown that principals in Israel, for example, report fewer problems with classroom disturbances, intimidation of students and injury to students than principals in the United States (Martin, Mullis, \& Foy, 2008).

Nevertheless, our findings do indicate that the school experience for LGBT youth in the United States is, by and large, more negative than for those youth in Israel. Although one might posit that differences in anti-LGBT bullying and harassment might be related to general population attitudes in the country, that may not necessarily explain why the U.S. LGBT youth reported higher incidences. As mentioned previously, recent polling on attitudes toward LGBT people have shown that the United States is more accepting than Israel, especially among younger adults. One possible explanation is that the normative nature of the school day varies between the two countries. It may be that the school day allows for more unsupervised time where students have the opportunity to perpetrate such acts. LGBT students in both countries were more likely to report being targeted in places such as bathrooms, hallways, and school grounds.

Although the U.S. youth reported higher levels of victimization than their Israeli peers, U.S. youth also reported more supportive resources to LGBT students than did Israeli youth. Certain resources, such as extracurricular activities for LGBT students, are more likely because these types of activities such as clubs and afterschool activities, in general, are more common in U.S. schools. The only extracurricular activity for LGBT students in Israel is a guest lecture, which is offered by one national LGBT NGO. Access to this guest lecture is shaped by school-level and NGO-level factors (e.g., supply and demand). With books and library materials, it may be that the production of LGBT-related books and materials is associated with history of the LGBT movement in each country. It may also reflect the more localized oversight of schools in the United States. That is, local school districts and even individual schools may have more latitude in the materials they have available for students in general. Given that Israel has a national curriculum, it may be less likely that local schools in Israel have supplemental materials that go beyond the limits of that national curriculum. It is less easy to posit reasons why U.S. students were more likely to have teachers and school staff who were supportive of LGBT students. Perhaps the attitudes of school staff are simply reflective of differences in general population attitudes toward LGBT people, which are more positive in the United States. It is also possible that U.S. teachers were more exposed to LGBT issues in their preservice learning. More research is needed to understand the nature of teacher attitudes and LGBT issues in the two countries. Last, differences in resources may be related to differences in advocacy work between the two countries. As an example, when considering the histories of the two organizations involved in these studies, GLSEN as a national organization was founded 10 years earlier than IGY. GLSEN has also been focused exclusively on 
K-12 education, whereas IGY has focused on nonformal education, such as social groups and youth centers.

Whereas U.S. LGBT students were more likely to hear homophobic remarks and report higher levels of victimization than Israeli LGBT students, they reported more LGBT supports at school. Given that these data are cross-sectional, we cannot know the direction of effects, but it may be that the higher level of support is in reaction to higher levels of victimization in U.S. schools. However, findings on change over time in the United States have shown that there has been significant decrease in the prevalence of anti-LGBT remarks and victimization at school only in recent years, whereas there have been more strides in increasing the availability of affirmative LGBT supports (Kosciw et al., 2014). In Israel, there has been no almost change in the prevalence of anti-LGBT remarks and victimization at school, and small increase in the availability of affirmative LGBT supports (Pizmony-Levy \& Shilo, 2012; Shilo \& Pizmony-Levy, 2008). Thus, in both the United States and Israel contexts, it appears that it may take time for resources to show effect on school climate.

When considering the differences in the effect of negative school climate indicators on academic outcomes, we found that hearing homophobic remarks and experiences of victimization were significantly related to both educational indicators (i.e., missing school and school belonging), and the independent variables together resulted in similar contributions, consider the pseudo $R^{2}$, in both samples. However, there were a few striking differences in the strength of relationships. Regarding missed days of school for the Israeli youth, physical assault and homophobic remarks were the strongest predictors. Yet, for the U.S. youth, physical assault and verbal harassment were the strongest predictors. It may be that the constructs for homophobic remarks and verbal harassment, as assessed in the surveys, are not wholly equivalent in the two school contexts. Whereas homophobic remarks are not directed at students and verbal harassment may involve similar language but are directed at the students themselves. It is possible that the nuances of this distinction translate differently between the two cultures literally and figuratively. The nuance of the language may not be as clear in the Hebrew version versus the English version. It is also possible that the manner in which less direct hostile actions have a different effect on a student's feelings of discomfort.

For school belonging, on the other hand, we saw similar patterns in the relationships of homophobic remarks and verbal harassment between the two samples. For U.S. youth, all four independent variables: homophobic remarks, verbal and sexual harassment and physical assault. However, in the Israeli sample, physical assault was not a significant predictor. It is possible that some of this is because how connected one feels to school could be an intermediary variable between hostile climate and missing school. However, when we examined Model 1 in Table 5 but included sense of belonging to school as an additional covariate, the pattern of relations between the indicators of school climate and missing school appeared similar. Thus, it may be that school climate affects LGBT students' feelings of school 
belonging similarly in the two samples, but the types of negative experiences that contribute most to missing school are somewhat different. Alternatively, this may be, in part, because of statistical power given the sample sizes in each sample.

Sexual harassment was higher in the United States, but for both dependent variables, it had a stronger effect for Israeli LGBT youth. We cannot know if and how the nature of sexual harassment qualitatively differs across the two samples or the two youth populations. Nevertheless, it may be that this type of harassment has a different effect on the emotional well-being of students across the two populations, which would contribute to the educational variables examined here.

\section{Limitations}

This study expands upon the current research by comparing the school experiences of LGBT youth in two countries, also providing insight into how hostile school climate similarly affect youth in both contexts. Nonetheless, our study has several limitations. First, there are potential limitations to the generalizability of the findings. Both samples consists of youth who already define themselves as LGBT and therefore may exclude youth who will eventually identify as LGBT but may not yet do so; likewise, it includes youth who currently identify as LGBT but may not in the future. We cannot make determinations from the data about the experiences of youth who might be engaging in same-sex sexual activity or experiencing same-sex attractions but who do not identify themselves as lesbian, gay or bisexual. Such youth may have experiences that differ from those of youth who identify as lesbian, gay or bisexual-they may be more isolated, they may not be aware of supports for LGBT youth, or, even if aware, may not be comfortable using such supports. Similarly, not all youth whose gender identity or gender expression is outside of cultural norms may experience themselves as or identify as transgender, or even have the resources to understand what being transgender means. Thus, the data may not reflect the experiences of these youth, who may also be more isolated and without the same access to resources as the transgender youth in the survey. And there may be unknown differences between sexuality and gender identity development between U.S. and Israeli cultures.

Second, although the methods for obtaining participants were similar in both countries, differences in the two samples may be related to factors in sampling. There is no clear comparative indicator in either sample for how involved in LGBT community activities and youth in one country may be more connected directly to the organization conducting the study than in the other. Similarly, as social media was employed more in advertising the studies in the United States and this may have allowed for a more representative and/or diverse sample reflecting the U.S. LGBT youth population. However, because there are no national statistics on the demographic breakdown of LGBT-identified youth in either country, 
we cannot know how well the samples represent either of the general LGBT youth populations.

Third, and final, the data presented here were cross-sectional. The two samples were collected one year apart. It is possible that there were historical effects that would make them less comparable. However, we maintain that such possible effects would not necessarily influence the findings on the relation between school climate and academic outcomes, because those are within each country sample, but they could influence the comparisons between the two samples.

\section{Considerations for further comparative research}

Although the IGY survey was modeled closely after the GLSEN survey, both in instrumentation and method, the two surveys were not intentionally designed for comparative purposes. In the key indicators of anti-LGBT behaviors and events at school, there were slight differences in assessment. Using the homophobic remarks construct as an example, the U.S. question about hearing "gay" used in a negative way, as in "that's so gay," is assessing language use that may be specific to North America. "Gay," in that usage, is meant to indicate something bad or worthless or boring. The U.S. question is asking about the usage of a word that is not necessarily pejorative, but it becomes pejorative in this usage. In this way, it is not equivalent to the two IGY questions about hearing "homo" or "lesbian" in a negative way. Those two questions are more similar to use of pejorative slang, such as "fag" or "dyke." We maintain that the computed variable within each sample reflects the same construct of "hearing homophobic remarks," but the individual items were not wholly comparable across samples. This is an example of a specific phenomenon of pejorative remarks regarding LGBT people that is potentially unique in certain country contexts, and there may be no parallel in other country contexts or perhaps there is, but it was untapped in the Israeli study. This raises the question as to what are the priorities in constructing a measure to be used internationally. If the goal is to assess a certain phenomenon yet the phenomenon may manifest itself differently in different country contexts, then it becomes a choice between a truer assessment of the phenomenon or more parallel survey items.

Issues related to translation and semantics are clearly challenging when assessing pejorative language use, but it is not exclusive to issues of language use. Sexuality and gender identity in the United States and Israel may be more similar to one another and to other Western or European countries, but not necessarily so when comparing to non-Western, non-European cultures. Nanda (2014) wrote: "significant cultural variation occurs in what is considered appropriate sexuality-desire, orientation, practices-for different genders and in the presumed relation between sex/gender diversity, sexuality, and gender identity" (p. 5). Thus, future research must carefully consider the presumed population of interest and whether it is comparable across nations-what the LGBT community of students is in the United States or Israel may not necessarily be the same worldwide. Similar to international 
large-scale assessments of student achievement (e.g., Trends in International Mathematics and Science Study), this study indicates the need for the development of an international instrument done a priori, collectively with researchers and LGBT community experts representing the various countries involved.

Previous research from both GLSEN (Kosciw et al., 2014; Kosciw, Greytak, \& Diaz, 2009) and IGY (Pizmony-Levy et al., 2008; Pizmony-Levy \& Shilo, 2012; Shilo \& Pizmony-Levy, 2008) have examined within-country factors influencing school climate for LGBT youth, including community attitudes toward LGBT people. However, in the present study, we were not able to fully examine the role that general societal attitudes toward LGBT people have on and in the school contextas there were only two countries, societal attitudes would be a redundant variable. Only by including other country cases can we really examine how general attitudes toward LGBT people affect the experiences of LGBT youth in schools at a national level.

The present study has provided some initial insight into how the experiences of LGBT students are similar in different country contexts. Yet, it also illustrates some key differences both in the prevalence of anti-LGBT behaviors in school and how these occurrences affect LGBT students. In all, the present study highlights the need for further comparative research on LGBT students across multiple country contexts. Through such research, we will better understand the experiences of this population in each country, and will provide important benchmarks for global advocacy.

\section{Notes}

1. In the GLSEN survey, less than $5 \%$ of the sample was collected through community-based groups serving LGBT youth, whereas in the IGY survey, nearly a quarter $(22 \%)$ of the sample was collected through this method.

2. About one third of LGBT students in Israel (30.2\%) indicated that they have no supportive resources in their school. Similar portion (31.9\%) indicated they have one resource. The rest, slightly less than two fourths (37.9\%) indicated that they have two or more resources.

\section{Notes on contributors}

Oren Pizmony-Levy is an Assistant Professor of International and Comparative Education at Teachers College, Columbia University. Trained as a sociologist, he is broadly interested in education, globalization, and transnational social movements. In one line of research he examined the experience of Israeli LGBT youth in schools and in the military. He is currently exploring the work of non-governmental organizations (NGOs) serving LGBT youth and students worldwide, and public opinion toward the LGBT-related curriculum.

Joseph G. Kosciw is the Chief Research and Strategy Officer at GLSEN (the Gay, Lesbian and Straight Education Network). GLSEN is U.S.-based NGO whose mission is to ensure safe and affirming K-12 educational environments for all students, regardless of sexual orientation and gender identity and gender expression. He is a community psychologist by training and has also been a school counselor and family therapist. He started GLSEN's research program in 2001 and now also oversees GLSEN's education and youth programs and its international program. 


\section{References}

Adam, B. D., Duyvendak, J. W., \& Krouwel, A. (2009). The global emergence of gay and lesbian politics: National imprints of a worldwide movement. Pennsylvania, PA: Temple University Press.

Arnove, R. F., Torres, C. A., \& Franz, S. (Eds.). (2012). Comparative education: The dialectic of the global and the local. Lanham, MD: Rowman \& Littlefield.

Bontempo, D. E., \& d'Augelli, A. R. (2002). Effects of at-school victimization and sexual orientation on lesbian, gay, or bisexual youths' health risk behavior. Journal of Adolescent Health, 30(5), 364-374.

Bray, M., Adamson, B., \& Mason, M. (Eds.). (2007). Comparative education research: Approaches and methods (Vol. 19). Hong Kong, China: Springer Science \& Business Media.

Cornu, C. (2016). Preventing and addressing homophobic and transphobic bullying in education: A human rights-based approach using the United Nations Convention on the Rights of the Child. Journal of LGBT Youth, 13 (1-2),

Currie, C., Roberts, C., Morgan, A., Smith, R., Settertobulte, W., Samdal, O., \& Barnekow Rasmussen, V. (2004). Young people's health in context: International report from the Health Behavior in School-Aged Children (HBSC) study. World Health Organization. Retrieved from http://www.euro.who.int/__data/assets/pdf_file/0008/110231/e82923. pdf

Eick, U., Rubinstein, T., Hertz, S., \& Slater, A. (2016). The change in attitudes of high school students in Israel towards homosexuals. Journal of LGBT Youth, 13(1-2), 192-206.

Foshay, A. W. (1962). Educational achievements of thirteen-year olds in twelve countries: Results of an international research project, 1959-61. Hamburg, Germany: UNESCO.

Goodenow, C. (1993). The psychological sense of school membership among adolescents: Scale development and educational correlates. Psychology in the Schools, 30(1), 79-90.

Harel, A. (1999). The rise and fall of the Israeli Gay Legal Revolution. Columbia Human Rights Law Review, 31, 443-472.

Hillier, L., Jones, T., Monagle, M., Overton, N., Gahan, L., Blackman, J., \& Mitchell, A. (2010). Writing Themselves In III. The third national study on the sexual health and well-being of same sex attracted and gender questioning young people. Melbourne: Australian Research Centre in Sex, Health and Society, La Trobe University.

Horn, S. S., Kosciw, J. G., \& Russell, S. T. (2009). Special issue introduction: New research on lesbian, gay, bisexual, and transgender youth: Studying lives in context. Journal of Youth and Adolescence, 38(7), 863-866.

Kama, A. (2000). From terra incognita to terra firma: The logbook of the voyage of gay men's community into the Israeli public sphere. Journal of Homosexuality, 38(4), 133-162.

Kosciw, J. G., Diaz, E. M., \& Greytak, E. A. (2008). The 2007 National School Climate Survey: The experiences of lesbian, gay, bisexual and transgender youth in our nation's schools. New York, NY: GLSEN.

Kosciw, J. G., Greytak, E. A., \& Diaz, E. M. (2009). Who, what, where, when, and why: Demographic and ecological factors contributing to hostile school climate for lesbian, gay, bisexual, and transgender youth. Journal of Youth and Adolescence, 38(7), 976-988.

Kosciw, J. G., Greytak, E. A., Palmer, N. A., \& Boesen, M. J. (2014). The 2013 National School Climate Survey: The experiences of lesbian, gay, bisexual and transgender youth in our nation's schools. New York, NY: GLSEN.

Kosciw, J. G., Palmer, N. A., Kull, R. M., \& Greytak, E. A. (2013). The effect of negative school climate on academic outcomes for LGBT youth and the role of in-school supports. Journal of School Violence, 12(1), 45-63. 
Kosciw, J. G., \& Pizmony-Levy, O. (2013). Fostering a global dialogue about LGBT youth and schools. In Proceedings from a Meeting of the Global Network Combating Homophobic and Transphobic Prejudice and Violence in Schools Sponsored by GLSEN \& UNESCO. New York, NY: GLSEN.

Long, J. S. (1997). Regression models for categorical and limited dependent variables. Thousand Oaks, California: Sage.

Martin, M., Mullis, I., \& Foy, P. (2008). TIMSS 2007 International Science Report. Chestnut Hill, MA: TIMSS \& PIRLS International Study Center, Boston College.

Mullis, I., Martin, M., \& Foy, P. (2008). TIMSS 2007 International Mathematics Report. Chestnut Hill, MA: TIMSS \& PIRLS International Study Center, Boston College.

Organisation for Economic Cooperation and Development (OECD). (2012). Education at a Glance 2012: OECD Indicators. Paris: OECD Publishing.

Pew Charitable Trusts (2007). World publics welcome global trade - but not immigration: 47Nation Pew Global Attitudes Survey. Washington, DC: Pew Research Center.

Pizmony-Levy, O., Kama, A., Shilo, G., \& Lavee, S. (2008). Do my teachers care I'm gay? Israeli lesbigay school students' experiences at their schools. Journal of LGBT Youth, 5, 33-61.

Pizmony-Levy, O. \& Shilo, G. (2012). The 2012 School Climate Study: The Israeli education system from the perspective of lesbian, gay, bisexual and transgender students. Tel-Aviv, Israel: Israeli Gay Youth Organization.

Nanda, S. (2014). Gender diversity: Crosscultural variations. Long Grove, IL: Waveland Press.

Shilo, G., \& Pizmony-Levy, O. (2008). The 2008 School Climate Study: The Israeli education system from the perspective of lesbian, gay, bisexual and transgender students. Tel-Aviv, Israel: Israeli Gay Youth Organization.

Takacs, J. (2006). Social exclusion of young lesbian, gay, bisexual and transgender people in Europe. Brussels, Belgium: ILGA-Europe and IGLYO.

Taylor, C. \& Peter, T., with McMinn, T. L., Elliott, T., Beldom, S., Ferry, A., Gross, Z., Paquin, S., \& Schachter, K. (2011). Every class in every school: The first national climate survey on homophobia, biphobia, and transphobia in Canadian schools. Toronto, Ontario, Canada: Egale Canada Human Rights Trust.

Thapa, A., Cohen, J., Guffey, S., \& Higgins-D’Alessandro, A. (2013). A review of school climate research. Review of Educational Research, 83(3), 357-385.

Toomey, R. B., \& Russell, S. T. (2013). Gay-straight alliances, social justice involvement, and school victimization of lesbian, gay, bisexual, and queer youth implications for school wellbeing and plans to vote. Youth \& Society, 45(4), 500-522.

Toomey, R. B., Ryan, C., Diaz, R. M., Card, N. A., \& Russell, S. T. (2010). Gender-nonconforming lesbian, gay, bisexual, and transgender youth: School victimization and young adult psychosocial adjustment. Developmental psychology, 46(6), 1580-1589.

Toomey, R. B., Ryan, C., Diaz, R. M., \& Russell, S. T. (2011). High school gay-straight alliances (GSAs) and young adult well-being: An examination of GSA presence, participation, and perceived effectiveness. Applied Developmental Science, 15(4), 175-185.

UNDP (2009). Human Development Report 2009: Overcoming Barriers: Human Mobility and Development. New-York: UNDP.

UNESCO (2012). Education sector responses to homophobic bullying. Paris, France: Author. Retrieved from http://unesdoc.unesco.org/images/0021/002164/216493e.pdf

Volansky, A. (2007). School autonomy for school effectiveness and improvement: The case of Israel. In T. Townsend (Ed.), International handbook of school effectiveness and improvement (pp. 351-362). Netherlands: Springer.

World Bank Group. (2016). World Development Indicators 2015. Washington DC: World Bank Publications. 